\title{
HUBUNGAN KOORDINASI DAN KEMAMPUAN APARATUR DENGAN KUALITAS PELAYANAN PUBLIK PADA KANTOR KECAMATAN HALONG KABUPATEN BALANGAN
}

\author{
Erna Suriyani \\ E-mail: ernasuryani65@yahoo.co.id
}

FIA-UVAYA Banjarmasin

\begin{abstract}
This study aims to determine the relationship of coordination and the ability of the apparatus to the quality of public services at the district office Halong Balangan.

This type of research used in this study is the type Eksplanatory, while the approach used is a quantitative approach. To prove the relationship of coordination and the ability of the apparatus to the quality of public services, will be analyzed using Chi Square models. Measuring the quality of care in this study refers to the majority opinion of Parasuraman, Zeithaml, and Berry (Tjiptono, 2004: 132) Levince in Ratminto (2005: 175). Factors affecting the quality of service inferred from Moenir opinion, The Liang Gie Fan Info and theory The Triangle of Service Quality proposed by Morgan and Murgatroyd.

The results of this study indicate that coordination with the quality of public services in dimensions realiability and Assurance at the district office Halong district Balangan good level of Significant $1 \%$ and $5 \%$ proved to be no correlation, while coordination with the quality of public services in the dimension Responsiveness, Empathy, Tangibles at level Significant $1 \%$ proved to be no relationship and the significant level of $5 \%$ proved no relationship. While the ability of personnel to the quality of public services in the dimensions of Reliability, Responsiveness, Assurance, Empathy and Tangibles at the district office Halong Balangan at significant level of $1 \%$ proved no hungan, while the significant level of $5 \%$ proved to be no relationship.
\end{abstract}

Keywords: Quality of Public Services, Coordination and Administrative Capabilities 


\section{PENDAHULUAN}

Pelayanan publik merupakan tugas utama dari aparatur sebagai abdi negara dan abdi masyarakat. Tugas ini telah jelas digariskan dalam pembukaan UUD 1945 alenia keempat, yang meliputi 4 (empat) aspek pelayanan pokok aparatur terhadap masyarakat, yaitu melindungi segenap bangsa Indonesia dan seluruh tumpah darah Indonesia, memajukan kesejahteraan umum, mencerdaskan kehidupan bangsa dan melaksanakan ketertiban dunia yang berdasarkan kemerdekaan, perdamaian abadi dan keadilan sosial.

Kita semua menyadari pelayanan publik selama ini belum dapat diberikan dengan secara optimal.Masyarakat sering dihadapkan pada begitu banyak ketidakpastian ketika mereka berhadapan dengan birokrasi. Amat sulit memperkirakan kapan pelayanan itu bisa diperolehnya dan terjangkau oleh masyarakat sehingga banyak orang yang

kemudian enggan berurusan dengan birokrasi publik.Walaupun ruang lingkup pelayanan publik sangat luas,namun seharusnya tetap diikuti oleh peningkatan kualitas birokrasi dalam memberikan pelayanan kepada masyarakat.

Kecamatan Halong merupakan salah satu Kecamatan di Kabupaten Balangan yang mana Kabupaten ini termasuk masih berusia muda hasil pemekaran dari Kabupaten Hulu sungai utara. Dengan demikian berarti birokrasinyapun masih relatif muda dalam hal ini termasuk kantor kecamatan Halong jika dibanding dengan Kabupaten yang ada di Kalimantan Selatan. Dengan pemekaran ini harapkan Kabupaten Balangan akan dapat membawa masyarakatnya lebih sejahtera.

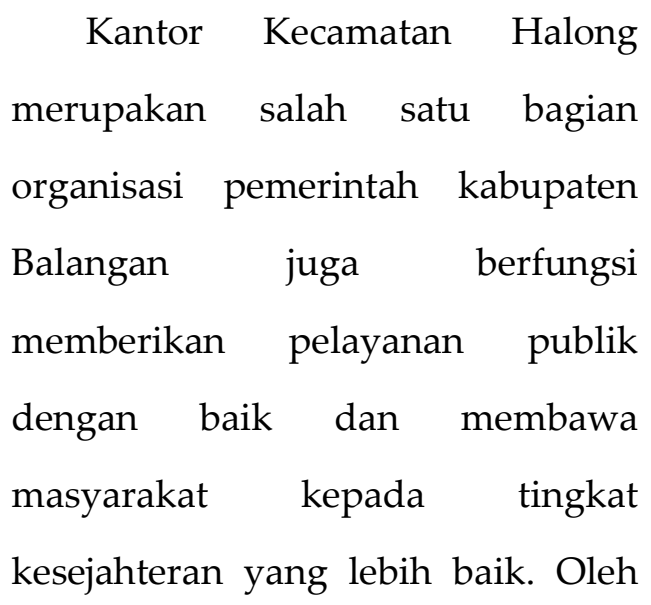


karena itu aparatur pada kantor Kecamatan Halong harus bekerja optimal agar tujuan tersebut diatas tercapai.

Namun, dalam perjalanannya masih banyak dijumpai permasalahan yang berkaitan dengan pemberian pelayanan kepada masyarakat. Telah banyak pengalaman dari sebagian masyarakat sebagai pengguna dari pelayanan publik yang mengeluhkan terhadap pelayanan yang telah diberikan. Fenomena ini menggam-barkan belum optimalnya kualitas pelayanan publik yang selama ini dinikmati oleh masyarakat. Sejauh ini ternyata tidak ada perbaikan yang berarti dalam penyelenggaraan pelayanan publik. Bahkan, harapan masyarakat bahwa pemekaran wilayah Kabupaten akan membawa perbaikan terhadap penyelenggaraan pelayanan publik ternyata makin belum dapat diwujudkan. Fungsi-fungsi yang seha-rusnya sudah dijalankan ternyata belum secara memuaskan dilaksanakan. Kalau dilihat dari kemampuan aparatur kecamatan Halong masih belum optimal hal ini dapat dilihat dari tingkat pendidikan mereka terbanyak adalah berpendidikan setingkat Sekolah Menengah Atas (SMA), bahkan masih ada yang berpendidikan SMP dan mau tidak mau masih ada eselon IV yang berpendidian SMA. Disamping itu dari hasil observasi menunjukan bahwa hubungan antar Pegawai Negeri Sipil (PNS) di berbagai seksi pada kantor Kecamatan Halong masih belum begitu harmonis.

Berdasarkan uraian diatas, maka penulis perlu untuk melakukan penelitian dengan tentang " Hubungan Koordinasi dan Kemampuan Aparatur dengan Kualitas Pelayanan Publik pada kantor Kecamatan Halong Kabupaten Balangan"

\section{TINJAUAN PUSTAKA}

\section{Variabel Koordinasi (X1)}

Menurut The Liang gie (2000:56) mengemukakan bahwa "Koordinasi adalah suatu kerjasama antara 
badan/ unit/instansi dalam keselarasan kerja antara yang satu pelaksanaan tugas tertentu dengan yang lain, sehingga sedemikian rupa sehingga terdapat diharapkan tidak terjadi kesimpangsaling pengertian,saling isi mengisi,saling membantu dan saling melengkapi" sedangkan menurut G.R Terry (2000:56) memberikan pendapatnya mengenai: Coordination is theerdely synchronization of effort to provide the proper amount, timing and directing of execution resulting in harmonious and unified actions to a stated objective (Koordinsi adalah suatu usaha yang sinkron dan teratur untuk menyediakan jumlah dan waktu yang tepat, dan mengarahkan pelaksanaan untuk menghasilkan suatu tindakan yang seragam dan harmonis pada sasaran yang telah ditentukan).

Kemudian menurut Alex S Nitisemito(1985:99) bahwa “Koordinasi adalah tindakan seorang manajer untuk mengusakan terjadinya keselarasan,antara tugas pekerjaan yang dilakukan oleh seseorang atau bagian yang lain.Maka dengan koordinasi ini dapat diartikan suatu usaha kearah siuran,ketidaktetapan, serta dobel pekerjaan antara yang satu dengan yang lainnya,hal ini bahwa pekerjaan akan dapat dilaksanaan secara efisien dan efektif".

Menurut Handoko (2003: 195) bahwa koordinasi sebagai proses pengintegrasian tujuan-tujuan dan kegiatan-kegiatan pada satuansatuan yang terpisah (departemen atau bidang-bidang fungsional) suatu organisasi untuk mencapai tujuan organisasi secara efisien. Sedangkan koordinasi menurut Anonim, 2003 dalam Husaini (2013: 488) adalah suatu sistem dan proses interaksi untuk mewujudkan keterpaduan, keserasian, dan kesederhanaan berbagai kegiatan inter dan antarinstitusi-institusi di masyarakat melalui komunikasi dan dialog-dialog antarberbagai individu dengan menggunakan sistem informasi manajemen dan tekonologi informasi. Dan koordinasi menurut Husaini (2013: 
489) itu sendiri adalah bagian penting di antara anggota-anggota atau unit-unit organisasi yang pekerjaannya saling bergantung. Semakin banyak pekerjaan individuindividu atau unit-unit yang berlainan tetapi erat hubungannya, semakin besar pula kemungkinan terjadinya masalah-masalah koordinasi.

Menurut M.C Farland dalam Handayaningrat (1990: 89) memberikan definisinya tentang: Coordination is the process whereby an executive develope an ordely patterns of group efforts among his subordinates and secure uniti of action in the persuit of comman purpose. (Koordinasi adalah suatu proses dimana pimpinan mengembangkan pola usaha kelompok secara teratur diantara bawahannya dan menjamin kesatuan tindakan di dalam mencapai tujuan bersama).

Koordinasi itu sebenarnya bertujuan yang menurut Alex.S. Nitisemito (1978:100) bahwa tujuan Koordinsi adalah agar tidak terjadi dobel pekerjaan,menghindarkan kesimpngsiuran,ketidaktepatan serta diharapkan lebih efisien dan efektive. Sedangkan alat ukur koordinasi yang memadai menurut M.C Farland dalam Handayaningrat (1990:89) adalah : Tanggung jawab, Ada proses, Pengaturan secara teratur daripada usaha kelompok,Konsep kesatuan tindakan,Tujuan koordinasi adalah tujuan bersama (common purpose).

Berdasarkan uraian tersebut di atas, maka dapat disimpulkan bahwa koordinasi merupakan upaya suatu organisasi untuk mennciptakan harmonisasi atau hubungan yang baik antar bagianbagian di dalam organisasi untuk mendapatkan hasil kerja yang optimal sehingga tujuan organisasi tercapai dengan baik dan cepat.

Definisi tersebut mengisyaraatkan bahwa tujuan organisasi akan dapat dicapai dengan efisien dan efektif bila koordinasi dilakukan dengan baik. Dengan koordinasi yang baik maka tidak akan terjadi tumpang tindih pekerjaan, kesimpangsiuran bahkan 
tidak terjadi kekosongan pekerjaan serta keharmonisan aparat dalam unit maupun antar unitpun akan tercipta.

\section{Variabel Kemampuan Kerja}

Sumber daya manusia (aparatur) adalah merupakan faktor yang sangat penting dalam suatu organisasi (institusi) karena sumberdaya manusia merupakan penggerak dari sumber-sumber daya lainnya yang digunakan organisasi. Oleh karena itu maka aparatur dalam aktivitas suatu pekerjaan pasti memerlukan kemampuan, karena tanpa adanya kemampuan tersebut, maka pekerjaan tidak akan dapat dikerjakan sesuai dengan yang dikehendaki. Oleh karena itu dalam bekerja kemampuan merupakan modal pertama yang harus dimiliki oleh aparatur/ pegawai. Berkaitan dengan hal tersebut Moenir (2001 :119) menyatakan bahwa:" Dengan kemampuan dan keterampilan yang mamadai maka pelaksanaan tugas/pekerjaan dapat dilakukan dengan baik,cepat dan memenuhi keinginan semua pihak,baik manajemen itu sendiri maupun masyarakat."

Kemampuan menurut Kamus Besar Bahasa Indonesia (2003:89) adalah merupakan kesanggupan melakukan sesuatu. Pemahaman sesuatu ini disesuaikan dengan posisi seseoorang, jika ia seorang pegawai, maka sesuatu itu adalah pekerjaannya. Jadi kemampuan merupakan kesanggupan seorang pegawai untuk melakukan pekerjaan yang menjadi tanggung jawabnya.

Kemudian menurut Spencer (dalam Manulang, 2000:9) Kemampuan adalah sebagai suatu karakteristik dasar dari seorang individu yang secara sebab akibat berhubungan dengan referensi ukuran efektif atau kerja yang tiggi dalam suatu pekerjaan dan situasi.Sedangkan Kae Chung dan leon Megison (dalam Suharyati,2001:21) mendefinisikan kemampuan pegawai sebagai pelaksana yang dihubungkan dengan pekerjaan-nya dapat 
diartikan sebagai suatu keadaan pada diri seseorang yang secara bersungguh-sungguh bekerja, berdaya guna untuk melaksanakan pekerjaan sehingga memungkinkan suatu tujuan akan tercapai. Sementara itu Moenir (2002:116) kemampuan berasal dari kata mampu yang dalam hubungan dengan tugas/pekerjaan berarti dapat (kata sifat/keadaan) melakukan tugas /pekerjaan sehingga menghasilkan barang atau jasa sesuai dengan yang diharapkan.kata jadian kemampuan dengan sendirinya juga kata sifat/keadaan yang ditujukan pada sifat atau keadaan seseorang yang dapat melakukan tugas pekerjaan atas dasar ketentuan yang berlaku. Robin (2000:82) mengatakan bahwa kemampuan adalah kapasitas seseorang individu untuk mengerjakan berbagai tugas dalam suatu pekerjaan, dan kemampuan itu hakekatnya terdiri dari kemampuan intelektual dan kemampuan fisik. Gibson (2001:137) mendefinisikan kemampuan (ability) adalah: "Suatu kapasitas individu untuk mengerjakan berbagai tugas dalam suatu pekerjaan. Sedangkan kemampuan kerja(employee ability) meliputi kecerdasan (attitude), kepribadian (personality), pengalaman (experince) pelatihan (training). Perhatian/keterkaitan (interest). Pendidikan (eduucations) dan daya tarik (intelligence).

Dari beberapa definisi tersebut dapat disimpulkan bahwa kemampuan adalah kompetensi atau keadaan yang dimiliki seseorang baik berupa pendidikan dan pelatihan ,pengetahuan dan keterampilan serta pengalamannya untuk dapat menyelesaikan suatu pekerjaan sesuai dengan ketentuan yang yang telah ditetapkan.

Berkaitan dalam hal kualitas pelayanan publik, maka kemampuan aparat sangat berperan penting dalam hal ikut menentukan kualitas pelayanan publik tersebut. Untuk itu indikator-indikator dalam kemampuan aparat adalah sebagai berukut : 
1) Tingkat pendidikan aparat;

2) Kemampuan penyelesaian pekerjaan sesuai jadwal;

3) Daya serap pengetahuan pendidikan formal

4) Keikutsertaan dalam pelatihan

5) Pengalaman Kerja

6) Keterampilan yang dimiliki

\section{Pengertian Pelayanan publik}

Menurut Moenir (2002:6) arti pelayanan umum tidak lepas dari arti kepentingan umum, yaitu: "Setiap kegiatan yang bertujuan untuk memenuhi kepentingan orang banyak. Kepentingan umum diartikan sebagai himpunan kepentingan pribadi yang telah bersatu dan tidak bertentangan dengan norma masyarakat dan aturan yang berlaku".Sedangkan berdasarkan Keputusan Menteri Pendayagunaan Aparatur Negara Nomor 63 Tahun 2003, definisi pelayanan umum atau pelayanan publik adalah :“segala bentuk jasa pelayanan, baik dalam bentuk barang publik maupun jasa publik yang pada prinsipnya menjadi tanggung jawab dan dilaksanakan oleh instansi pemerintah di pusat, di daerah, dan di lingkungan BUMN atau BUMD, dalam rangka upaya pemenuhan kebutuhan masyarakat maupun dalam rangka pelaksanaan ketentuan peraturan perundangundangan. Sementara itu menurut Kurniawan dalam Sinambela (2008:5). Pelayanan publik adalah pemberian layanan (melayani) keperluan orang atau masyarakat yang mempunyai kepentingan pada organisasi itu sesuai dengan aturan pokok dan tata cara yang telah ditetapkan. Sementara itu Rohman (2008:3) mendefinisikan pelayanan publik adalah suatu pelayanan atau pemberian terhadap masyarakat berupa pennggunaan fasilitasfasilitas umum, baik jasa maupun non jasa, yang dilakukan organisasi publik, dalam hal ini adalah suatu pemerintahan. Hal senada juga diungkapkan oleh Saefullah (2008:5) bahwa pelayanan umum (public service) adalah pelayanan yang diberikan pada masyarakat umum yang menjadi warga negara atau 
yang secara sah menjadi penduduk negara yang bersangkutan. Kemudian pelayanan publik menurut Ndraha (2000:58) yaitu proses produksi barang dan jasa yang ditujukan kepada public sedangkan Soedarmayanti (1999:195) mengungkapkan bahwa yang dimaksuddengan pelayanan umum adalah "melayani suatu jasa yang dibutuhkan oleh masyarakat dalam segala bidang."

Dapat disimpulkan bahwa pelayanan publik adalah seluruh kegiatan pelayanan yang dilaksanakan oleh aparatur negara sebagai penyenggara pelayanan dalam suatu institusi atau organisasi pemberian pelayanan (melayani) keperluan orang lain atau masyarakat yang mempunyai kepentingan pada organisasi itu sesuai dengan aturan pokok dan tata cara yang telah ditetapkan

\section{Kualitas Pelayanan Publik.}

Menurut Wyckof (Tjiptono, 2004:59) Kualitas pelayanan adalah tingkat keunggulan yang diharapkan dan pengendalian atas tingkat keunggulan tersebut untuk memenuhi keinginan pelanggan. Apabila jasa atau pelayanan yang diterima atau dirasakan (perceived service) sesuai dengan yang diharapkan, maka kualitas jasa atau pelayanan dipersepsikan baik dan memuaskan. Jika jasa atau pelayanan yang diterima melampaui harapan pelanggan, maka kualitas jasa atau pelayanan dipersepsikan sebagai kualitas ideal. Sebaliknya jika jasa atau pelayanan yang diterima lebih rendah dari yang diharapkan, maka kualitas jasa atau pelayanan dipersepsikan buruk.

Gasperz, (Lukman, 2000:7) mengungkapkan sejumlah pengertian pokok dari kualitas pelayanan, yaitu:

1. Kualitas terdiri dari sejumlah keistimewaan produk, baik keistimewaan langsung, maupun keistimewaan atraktif yang memenuhi keinginan pelanggan dan dengan demikian memberikan kepuasan atas penggunaan produk itu.

2. Kualitas terdiri dari segala sesuatu yang bebas dari segala kekurangan atau kerusakan. 
Berdasarkan definisi tersebut diatas dapat disimpulkan bahwa kualitas pelayanan merupakan tingkat keunggulan yang dilakukan oleh instansi atau lembaga untuk memenuhi harapan masyarakat. Kualitas pelayanan lebih menekankan aspek mutu layanan yang diberikan kepada masyarakat pelanggan yang diberikan oleh instansi yang menawari jasa. Keberhasilan suatu instansi yang bergerak dalam pelayanan publik tergantung pada instansi yang bergerak dalam pelayanan publik tergantung pada kualitas pelayanan yang diberikan.

Lukman (2000:12) yang menyatakan bahwa: "Kualitas pelayanan berhasil dibangun apabila pelayanan yang diberikan kepada pelanggan mendapatkan pengakuan dari pihak-pihak yang dilayani. Pengakuan terhadap keprimaan sebuah pelayanan, bukan datang dari aparatur yang memberikan pelayanan, melainkan datang dari pengguna jasa layanan." Hal senada pun diungkapkan oleh Tjiptono
(2004:61) yang menyebutkan bahwa: “Citra kualitas pelayanan yang baik bukanlah yang berdasarkan sudut pandang atau persepsi penyedia jasa, melainkan berdasarkan sudut pandang atau persepsi pelanggan. Pelangganlah yang mengkonsumsi dan menikmati jasa, sehingga merekalah yang seharusnya menentukan kualitas pelayanan umum. Persepsi pelanggan terhadap kualitas jasa atau pelayanan merupakan penilaian menyeluruh atas keunggulan suatu pelayanan."

Untuk dapat menilai bagaimana mutu pelayanan publik yang diberikan oleh aparat birokrasi, perlu adanya kriteria dimensi atau indikator yang menunjukkan suatu pelayanan publik yang diberikan itu dapat dikatakan baik atau buruk. Ukuran kualitas pelayanan tidak hanya ditentukan oleh penyedia layanan saja, akan tetapi justeru lebih banyak ditentukan oleh para pengguna layanan, dalam hal ini adalah masyarakat.

Menurut

Parasuraman,

Zeithaml, dan Berry (Tjiptono, 
2004:132) berpendapat bahwa ada lima indikator kualitas pelayanan, yaitu: Reliability (Keandalan), Responsiveness (Daya Tanggap), Assurance (Keyakinan), Empathy (Perhatian), Tangibles (Berwujud). Senada dengan Levince dalam Ratminto (2005:175) melihat kualitas pelayanan dari indikator-indikator sebagai berikut: 1)Responsiveness (Responsivilitas) 2)Responsibility (Responsibilitas) 3)Accountability (Akuntabilitas).

Berdasarkan uraian mengenai dimensi kriteria atau indikator diatas, maka fenomena kualitas pelayanan yang akan penulis cermati dalam penelitian ini adalah:

1) Kehandalan pelayanan

2) Daya tanggap petugas pelayanan (responsiveness);

3) Jaminan pelayanan (assurance);

4) Empati petugas pelayanan (empaty);

5) Kondisi lingkungan tempat pelayanan (tangibles);

5. Faktor-faktor yang Mempengaruhi Kualitas Pelayanan
Dalam proses pelayanan umum terdapat faktor yang sangat menentukan. Faktor-faktor yang menentukan tersebut berbeda-beda, namun masing-masing mempunyai pengaruh terhadap pelayanan baik sendiri-sendiri maupun secara bersama-sama. Moenir (2002:88) menyebutkan faktor yang akan mewujudkan pelaksanaan yang baik. Faktor-faktor tersebut antara lain:

1)Faktor kesadaran,

2)Faktor aturan,

3)Faktor organisasi,

4)Faktor pendapatan,

5)Faktor kemampuan-keterampilan,

6)Faktor sarana

The Liang Gie dan Budi Ibrahim (dalam Suwarsono, 1999:17) mengatakan bahwa faktor-faktor yang mempengaruhi kualitas pelayanan meliputi:

1) Motivasi kerja;

2) Kemampuan kerja pegawai;

3) Perlengkapan dan fasilitas;

4) Lingkungan eksternal;leadership;

5) Misi strategis; 
6) Budaya perubahan;

7) Kinerja individu dalam organisasi;

8) Praktik manajemen;

9) Struktur;

10) Iklim organisasi. Sedangkan Berdasarkan Peraturan Menteri Komifopan Nomor 8 Tahun 1992 mengatakan bahwa pelayanan yang baik/berkualitas ditentukan oleh: (1) sense of public service yaitu kesadaran untuk melayani, serta (2) kemampuan dan keterampilan petugas.

Kemudian menurut teori The Triangle of Service Quality yang dikemukakan oleh Morgan dan Murgatroyd (dalam warsito utomo: 1997) kualitas pelayanan terdiri dari : Interpersonal component, Procedures environment/process component, and technical/professional component. Pada dasarnya dalam teori The Triangle of Service Quality ini, ada 3 (tiga) ketentuan pokok dalam melihat tinggi rendahnya suatu kualitas pelayanan publik, yaitu dapat digambarkan sebagai berikut: Gambar 1

Segitiga Keseimbangan dalam Kualitas Pelayanan

(The Triangle of Balance in Service Quality)

BAGIAN ANTAR PRIBADI

YANG MELAKSANAKAN

(Inter Personal Component)

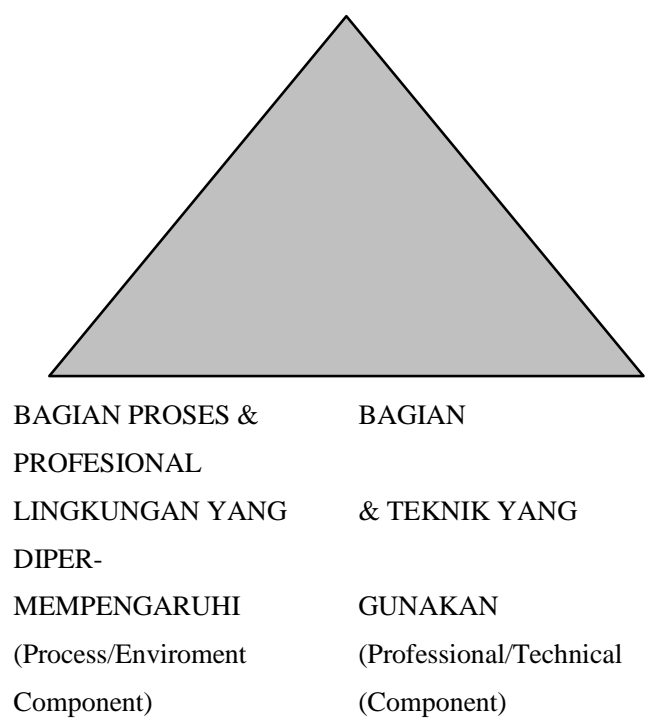

Dari gambar 1 tersebut menjelaskan bahwa dalam melihat tinggi rendahnya kualitas pelayanan publik perlu diperhatikan adanya keseimbangan antara :

1. Bagian antar pribadi yang melaksanakan (Inter Personal Component);

2. Bagian proses dan lingkungan yang mempengaruhi (Process and Environment Component);

3. Bagian profesional dan teknik yang dipergunakan (Professional and Technical Component). 
Model di atas merupakan suatu segitiga sama sisi di mana puncaknya adalah interpersonal component dari suatu pelayanan, sedangkan pada sisi sebelah kiri dari segitiga tersebut didapati konteks fisik dan prosedur serta komponen proses.

Pada sisi sebelah kanan didapatkan komponen teknis atau profesionalitas dalam menyampaikan pelayanan. Asumsi dari model ini adalah perlu dipertahankan keseimbangan dari tiga komponen tersebut di dalam menyediakan suatu pelayanan yang baik. Misalnya terlalu menekankan pada proses atau prosedur akan memberikan kesan pelayanan yang berbelit-belit dan rumit. Terlalu menekankan pada komponen interpersonal akan menimbulkan impresi bahwa penyedia jasa kurang memperhatikan profesionalitas pelayanan. Terlalu menekankan pada aspek profesional dan teknis dari pelayanan akan memberikan kesan bahwa pelayanan dilakukan secara profesional namun tidak ada perhatian khusus secara individual.Dari teori tersebut maka technical/professional component yang diturunkan menjadi variabel kemampuan pegawai dan procedures environment/process component menjadi variabel koordinasi yang mempengaruhi kualitas pelayanan.

Berdasarkan hal tersebut di atas maka dalam penelitian ini yang menjadi variabel Indevenden (X1) Koordinasi, Indevenden

Kemampuan Aparatur, dan Variabel Devenden (Y) adalah Kualitas Pelayanan. Sehingga paradigma dalam penelitian ini sebagai berikut: Koordinasi (X1)

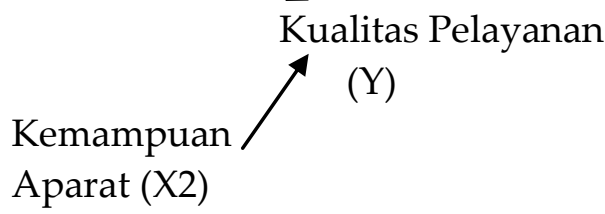

\section{METODOLOGI PENELITIAN}

Tipe penelitian yang digunakan pada penelitian ini adalah tipe Eksplanatory, dimana penulis ingin menguji hubungan Kemampuan Aparatur, koordinasi 
dengan Kualitas Pelayanan Pada kantor Kecamatan Halong Kabupaten Balangan. Pendekatan yang digunakan dalam penelitian ini adalah pendekatan kuantitatif.

Populasi dalam penelitian ini adalah seluruh pegawai kantor Kecamatan Halong Kabupaten Balangan, sampel yang digunakan adalah sampel total, memgingat jumlah pegawai sedikit, sehingga semua populasi dijadikan sampel.

Untuk membuktikan ada tidaknya hubungan Kemampuan kerja, koordinasi dengan kualitas pelayanan, akan dianalisa dengan menggunakan model Chi Kuadrat dengan rumus:

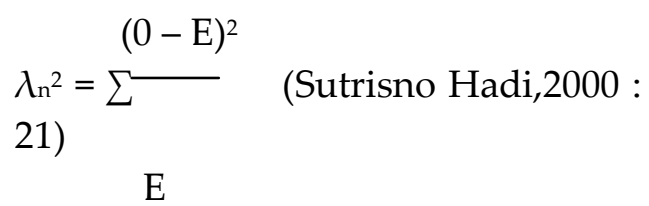

HASIL PENELITIAN DAN PEMBAHASAN.
1. HUBUNGAN KOORDINASI DENGAN KUALITAS PELAYANAN PUBLIK PADA KANTOR KECAMATAN HALONG KABUPATEN BA- LANGAN.

Analisa dalam penelitian ini yakni menguji Hubungan
Koordinasi dengan kualitas pelayanan publik pada kantor Kecamatan Halong Kabupaten Balangan, menunjukkan bahwa :

1) Hubungan Koordinasi dengan kualitas pelayanan publik dalam dimensi Realiability (Keandalan ) pada kantor kecamatan Halong kabupaten Balangan baik taraf Signifikan $1 \%$ dan $5 \%$ terbukti ada hubungan.

2) Hubungan Koordinasi dengan kualitas pelayanan publik dalam dimensi Responsiveness ( daya Tanggap).di kantor kecamatan Halong kabupaten Balangan. Pada taraf Signifikan 1\% terbukti tidak ada hubungan Sedangakan pada taraf Signifikan 5\% terbukti ada

3) Hubungan Koordinasi dengan kualitas pelayanan publik dalam dimensi Assurance atau Keyakinan pada kantor kecamatan Halong kabupaten Balangan ,baik pada taraf Signifikan $1 \%$ maupun $5 \%$ terbukti ada hubungan 
4) Hubungan Koordinasi dengan kualitas pelayanan publik dalam dimensi Empathy atau Perhatian pada kantor kecamatan Halong Kabupaten Balangan Pada taraf Signifikan 1\% terbukti tidak ada hubungan sedangkan pada taraf Signifikan 5\% terbukti ada hubungan.

5) Hubungan Koordinasi dengan kualitas pelayanan publik dalam dimensi Tangibles atau berwujud di kantor kecamatan Halong kabupaten Balangan,pada taraf signifikan $1 \%$ terbukti tidak ada hubungan sedangkan taraf signifikan $5 \%$ terbukti ada hubungan .

2. HUBUNGAN KEMAMPUAN APARATUR DENGAN KUALITAS PELAYANAN PUBLIK PADA KANTOR KECAMATAN HALONG KABUPATEN BALANGAN.

Analisa dalam penelitian ini yakni menguji Hubungan kemampuan aparatur dengan kualitas pelayanan publik pada kantor Kecamatan Halong
Kabupaten Balangan, menunjukkan bahwa :

1) Kemampuan aparatur dengan Kualitas pelayanan publik dalam dimensi Reliability atau Keandalan di kantor kecamatan Halong Kabupaten Balangan, pada taraf signifikan $1 \%$ terbukti tidak ada hungan, sedangkan pada taraf signifikan $5 \%$ terbukti ada hubungan.

2) Kemampuan aparatur dengan kualitas pelayanan publik dalam dimensi Responsiveness atau daya Tanggap di kantor kecamatan Halong kabupaten Balangan pada taraf signifikan $1 \%$ terbukti tidak ada hubungan, sedangkan pada taraf signifikan $5 \%$ ada hubungan.

3) Kemampuan aparatur dengan kualitas pelayanan publik dalam dimensi Assurance atau Keyakinan di kantor kecamatan Halong Kabupaten Balangan, pada taraf Signifikan $1 \%$ terbukti tidak ada hubungan sedangkan pada taraf Signifikan $5 \%$ terbukti ada hubungan. 
4) Kemampuan aparatur dengan kualitas pelayanan publik dalam dimensi Empathy atau Perhatian di kantor kecamatan Halong Kabupaten Balangan,pada taraf Signifikan $1 \%$ terbukti tidak ada hubungan, sedangkan pada taraf signifikan 5\% terbukti ada hubungan .

5) Kemampuan aparatur dengan kualitas pelayanan publik dalam dimensi Tangibles atau berwujud di kantor kecamatan Halong Kabupaten Balangan, pada taraf signifikan $1 \%$ terbukti tidak ada hubungan sedangkan pada taraf signifikan $5 \%$ terbukti ada hubungan.

\section{KESIMPULAN}

Berdasarkan hasil Penelitian dan pembahasan, dapat diambil beberapa kesimpulan sebagai berikut :

1) Koordinasi dengan kualitas pelayanan publik dalam dimensi Realiability (keandalan ) dan Assurance ( keyakinan), pada kantor kecamatan Halong kabupaten Balangan baik taraf
Signifikan $1 \%$ dan $5 \%$ terbukti ada hubungan, sedangkan Koordinasi dengan kualitas pelayanan publik dalam dimensi Responsiveness ( daya tanggap). Empathy(Perhatian) Tangibles (berwujud) pada kantor kecamatan Halong kabupaten Balangan Pada taraf Signifikan $1 \%$ terbukti tidak ada hubungan dan pada taraf Signifikan 5\% terbukti ada hubungan.

2) Kemampuan aparatur dengan Kualitas pelayanan publik dalam dimensi Reliability(Keandalan), Responsiveness (daya tanggap), Assurance(keyakinan), Empathy (perhatian) dan Tangibles(berwujud) pada kantor kecamatan Halong Kabupaten Balangan pada taraf signifikan $1 \%$ terbukti tidak ada hungan, sedangkan pada taraf signifikan $5 \%$ terbukti ada hubungan.

\section{Saran-Saran}

Berdasarkan kesimpulan dari hasil penelitian Hubungan koordinasi dan kemampuan aparatur dengan kualitas pelayanan 
publik di kantor Kecamatan Halong Kabupaten Balangan, maka hal-hal yang perlu disarankan untuk mendapatkan perhatian dalam rangka meningkatkan kualitas pelayanan publik adalah sebagai berikut : .

1) Koordinasi dan kerjasama pada setiap unit maupun antar unit perlu dilakukan dengan optimal, baik melalui rapat secara formal dan kontinu maupun dilakukan secara informal.

2) Kemampuan aparatur kantor Kecamatan Halong Kabupaten Balangan perlu ditingkatkan misalnya dengan cara memberikan kesempatan untuk seluas-luasnya untuk melanjutkan pendidikan kejenjang lebih tinggi dan lebih meningkatkan keikutsertaan mereka dalam kegiatan pelatihan, workshop dan sejenisnya dalam upaya meningkatkan kemampuan mereka dalam melaksanakan tugasnya terutama dalam hal memberikan pelayanan kepada masyarakat.

\section{DAFTAR PUSTAKA}

Departemen Pendidikan Nasional 2008. Kamus Besar Bahasa Indonesia Penerbit PT Gramedia Pustaka Utama Jakarta Edisi keempat.

Gibson, James,L.John MI James H. Donnely,1996 Organisani Prilaku, Struktur, Proses, Edisi ke delapan Bina Aksara Jakarta.

Gibson, James, L. John MI James H. Donnely, 1996 Organisani Prilaku, Struktur, Proses, Edisi ke delapan Bina Aksara Jakarta.

Hadi,Sutrisno, 2000, Statistik 2 yokyakarta Yayasan Penerbit Fakultas Psikologi Universitas Gajah Mada.

Handoko,T.Hani, 2005, Manajemen Personalia dan sumber Daya Manusia, Penerdit BPFE Yokyakarta.

Handayaningrat. 1990, Pengantar Ilmu Administrasi, Jakarta Mandar Maju.

$\begin{array}{lr}\text { Keputusan Menteri } & \text { Negara } \\ \text { Pendayagunaan } & \text { Aparatur } \\ \text { Negara } & \text { Nomor } \\ \text { 63/KEP/M.PAN/7/2003 } & \text { tentang } \\ \text { Pedoman } & \text { Umum } \\ \text { Penyelenggaraan } & \text { Pelayanan } \\ \text { Publik. } & \end{array}$

Lukman,Sampara.,2000."

Manajemen

Kualitas 
Pelayanan". Jakarta: STIA LAN Press.

Manulang, 2000 Manajemen Sumber Daya Manusia untuk Perusahaan, Penerbit Ghalia Indonesia, Jakarta.

Moenir,H.A.S, 2002,.Manajemen Pelayanan Umum di Indonesia. Jakarta : Bumi Aksara.

Ndraha,Taliziduhu,2000,Ilmu Pemerintahan Jilid I-IV.Jakarta: Institust Ilmu Pemerintahan.

Nitisemito, Alex. S. 1985 Pengantar Ilmu Administrasi,Jakarta Timur Ghalia Indonesia.

Nitisemito,Alex.S. 1978 Manajemen Suatu Dasar dan Pengantar, Jakarta Timur Ghalia Indonesia.

Raminto \& ATIK SW,2005 “Manajemen Pelayanan Umum Pengembangan Model Konseptual, Penerapan Citizen's Charter \& SPM,Pustaka Pelajar,Yogyakarta.

Robin,Stephen,P,2000,Prilaku

Organisasi Jilid Dua, PT. Prenhallindo Jakarta.

Rohman, A.A, dkk, 2008 Reformasi Pelayan, Malang: Program Sekolah Demokrasi PlaCIDS Averoes Dan KID.

Sudarmayanti,1999.Tugas-tugas dan Pengembangan Sekretaris. Bandung: Mandar Maju.
Saefullah,A,Djadja,2008.Pemikiran

Komteporer

Administrasi

Publik Perspektif manajemen Sumber daya Manusia dalam

Era

Desentralisasi,

Bandung;LP3AN Fisip UNPAD.

Tjiptono,Fandy,2004. Manajemen Jasa Yokyakarta; Andi offset.

Utomo, Warsito, 1997, Peranan dan Strategi Peningkatan Pendapatan Asli Daerah (PAD) dalam Pelaksanaan Otonomi Daerah, dalam Jurnal Ilmu Sosial dan Ilmu Politik, volume 1.

Usman, Husaini, 2013. Manajemen (Teori.Praktik, dan Riset Pendidikan, Jakarta. PT Bumi Aksara, Edisi Empat.

Suharyati Tesis 2001, Pengaruh Kemampuan disiplin dan Prosudur Kerja terhadap Kualitas Pelayanan, Balai Pengobatan Prov. Jawa Tengah.

Simambela.L.P,2008.Reformasi

Pelayanan Publik

:Teori,Kebijakan dan

Implementasi,Jakarta: Bumi.

Aksara.

Suwarsono,1999, Manajemen

Kualitas Pelayanan, PT Mandala

Krida Jakarta.

Suwarsono,1999, Manajemen

Kualitas Pelayanan, PT Mandala

Krida Jakarta. 
Terry,G.R,2000 Office Management and Control,Fourth edition Richart D Irwin Inc Homwood.

The Liang Gie.2000. Administrasi Perkantoran Modern.Gajah Mada University

Prss.Yoyakarta. 